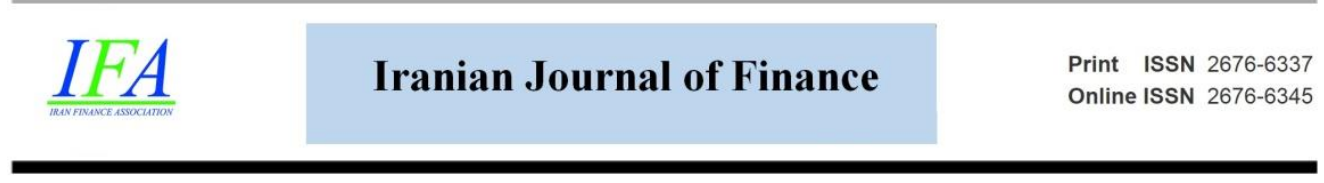

\title{
The Impact of Anchoring Bias and Disposition Effect on Momentum Profit: The Role of Stock Liquidity
}

\section{Fatemeh Soltani}

Ph.D. Candidate, Department of Accounting, Isfahan (Khorasgan) Branch, Islamic Azad University, Isfahan, Iran. (Email: solfa832002@yahoo.com)

\author{
Afsaneh Soroushyar* \\ *Corresponding Author, Assistant Prof., Department of Accounting, Isfahan \\ (Khorasgan) Branch, Islamic Azad University, Isfahan, Iran. (Email: \\ a_soroushyar@yahoo.com)
}

\section{Masoud Fooladi}

Assistant Prof., Department of Accounting, Shahin Shahr Branch, Islamic Azad University, Isfahan, Iran. (Email: foladim57@gmail.com)

Document Type: Original Article

Received: 2021/07/04

Accepted: 2021/11/28
2022, Vol. 6, No. 1. 82-116.

Published: 2022/02/09

\begin{abstract}
Researchers examined anomalies in the market to understand the market dimensions. Prior studies considered the effects of biases on momentum strategy. Stock liquidity as one of the risk factors for assets was also considered by researchers. The purpose of this study is to examine the role of stock liquidity in the separately and jointly effect of anchoring bias and the disposition effect on momentum profit. The population of this study consists of all companies listed on the Tehran Stock Exchange. Based on systematic election sampling this study covers 136 companies over the period of 20072020. In this study, the effect of disposition effect is calculated using the approach of Greenblatt and Han (2005) and Frazzini (2006) and the anchorage bias is calculated according to George and Hwang (2004). This study calculates
\end{abstract}


momentum profits according to Jegadeesh and Titman (1993). To test the hypotheses, multivariate regressions and the five-factor model of Fama and French (2015) have been used. The results of this study show that the disposition effect in stocks with low liquidity increases momentum profit. In addition, anchoring bias in stocks with low liquidity leads to an increase the momentum profit. Findings of this study document that the interaction effect of anchoring bias and disposition effect, while reinforcing each other, is also associated with increasing in momentum profit. Finally, when anchoring bias and disposition effect reinforce each other, and stocks have low liquidity, they do not increase momentum profits.

Keywords: Anchoring Bias, Disposition Effect, Stock Liquidity, Momentum Profit

DOI: https://doi.org/10.30699/IJF.2021.293531.1249

Publisher: Iran Finance Association

Type of License: Creative Commons License (CC-BY 4.0)

\section{Introduction}

Financial scientists' attention to psychological issues and researches cause to open a new vision in the capital market which is considered as a kind of revolution in the attitude to the basic principles of classical finance. Therefore, two basic principles of market efficiency and the rationality of investors in the real world are considered by financial scientists. Behavioral and cognitive biases of investors have an important role in economic decisions. The theory of cognitive anomalies is originally presented by Festinger in 1957 and developed by the perspective theory of Kahneman and Tursky (1979).

Prior studies on behavioral biases show that minority and institutional investors are reluctant to recognize their losses but more interested to recognize their profits. Therefore, they prefer to sell the beneficial stocks but hold the detrimental stocks. This behavior of investors is originally titled under the disposition effect by Shefrin and Statman in 1985. With the introduction of the disposition effect as an explanation for the aspects of the capital market bias, researchers have studied the effect on the launch of momentum in different markets (Grinblatt and Han 2005, Frazzini 2006 and O'Brien and Best 2017). They find that the disposition effect slows down the flow of information leading to price determination and helps explain stock volatility, stock returns, 
trading volume, and increases momentum stock returns. Consequently, in the field of recognizing behavioral bias, a new concept was considered by researchers named the momentum strategy or investment strategy in the direction of the market. Jegadeesh and Titman (2006) concluded that securities that performed well (badly) in the past tend to have pursued this performance in the future. This kind of stock prices momentum was defined as one of the strongest anomalies in the capital market. George and Hwang (2004) referred to the anchoring bias of investors as a substitute stimulus in explaining the stock price momentum.

Anchoring indicates when individuals make quantitative estimates influenced by previous estimates or available figures, their decisions in the future will be influenced by current and past information. According to Kahneman (1979), anchoring bias causes investors to have less reaction to new information and provide the conditions to misprice stock and increase momentum. Hao et al. (2018) showed that investors' decisions are influenced by their behavioral aspects. They indicated that anchoring at the highest price of 52 weeks intensifies momentum profits when investors' decisions are influenced by their emotions. Prior financial studies showed that different variables affect the momentum profitability strategy such as liquidity and stock volume (Averamov et al. (2007) and Sadka (2006). They documented the relationship between stock liquidity and momentum profitability strategy.

They indicated that a liquidity strategy may cause many anomalies in stock returns. Therefore, researchers consider the role of stocks' liquidity to describe the market anomalies. Hendershott and Riordan (2011), Cordial et al (2008, 2011, and 2014) find that with increasing frequency of institutional and partial transactions, liquidity increases. Consequently, price arbitrage decreases and market anomalies will be corrected, and market efficiency generally increases. They believe that illiquid stocks receive information lately. As a result, the overpricing and underpricing of stocks in which prices are far away (close to) from the 52-week high price will increase; the outcome amplifies momentum in stock prices. So, illiquidity intensifies the momentum arising from the disposition effect and anchoring bias.

Findings of recent studies in this area are divergent depending on different markets. For example, Hur and Singh (2019) examined the disposition effect and anchoring bias on momentum profit. They document an inverse effect of stock liquidity on momentum profits. While Tan and Cheng (2019) find that liquidity is not a factor in the profitability of the momentum strategy in the Australian market. Regarding the effect of behavioral biases on decision making by investors and creating ambiguities for mispricing stock, this study 
aims to investigate the role of stock liquidity on the distinct and reciprocal effect of anchoring bias and the disposition effect on momentum profits in the Tehran Stock Exchange. The findings of this study contribute to the understanding of different dimensions of the Tehran Stock Exchange and provide investors with a clearer environment to make better decisions.

\section{Literature Review}

Regarding the momentum phenomenon in the capital market, many researchers paid attention to the effect of investors' behavior on this phenomenon, especially when their behavior is affected by a particular bias. Prior studies, examined the impact of the disposition effect, which is originally proposed by Shefrin and Statman (1985), and anchoring bias by George and Huang (2004), on the momentum profit. To identify stock market anomalies, the stock liquidity factor was also considered. Shefrin and Statman (1985) found that investors keep the loser too long and sell the winner too early. They called it disposition effect, a behavior known as the fear of remorse. The researchers, such as Odean (1998), Shapira and Venezia (2000), Grinblatt and Han (2005), confirm the existence of disposition effect in financial markets based on theoretical and empirical findings of the capital market.

A disposition effect is a form of trading in terms of limited rationality. The wrong and significant effect of this behavior on the trading, performance and cash flows of this type of investor has been proven. Grinblatt and Han (2005) have stated that the disposition effect has an effect on stock prices. Although the disposition effect has been strongly proven in empirical researches, the reasons for such behavior are still unclear. The disposition effect can be created by a rational reaction to new information. One of the reasons based on information that may create disposition effect is portfolio rebalancing and higher cost of harmful stock transactions compared to profitable stocks and confidential information hypothesis or confidential interpretations of public information about the fundamental value of stocks. One of the irrational factors to the creation of the disposition effect is the idea of returning to the average stock return and loss avoidance, which is a prominent feature of Kahneman and Tversky's theory of perspective.

The disposition effect is presented as a possible explanation for the momentum in stock prices (Barberis et al. and Frazzini, 2006). They state the psychological bias of investors affects their risk-taking. Hartzmark (2015) 
documented another interesting aspect of investor trading. Investors are more likely to sell winner stocks than the loser.

Anchoring bias is one of the cognitive biases that have a great impact on a person's decisions, judgments and individual's behavior, and beliefs. In the decision-making process, the mind relies on the first information, so it turns to the basic information or part of it and does not seek further. According to the "anchoring effect", usually the first options offered have a great influence on the choice of people among the available options (Festinger, 1957). The effect of anchoring was first proposed in 1974 by Kahneman and Tversky. These sciences believe that economic designers make full use of the cognitive orientations of people's brains to trap them.

Like ships that anchor on the sea bed, our thoughts can anchor on the bed of facts or superstitions, called the point of reference. In fact, anchoring is inclining and correlating the formation of our thoughts with these beliefs. George and Hwang (2004) use the anchoring bias as a substitute stimulus in explaining the stock price momentum. They argue that being close (or far) to the 52-week high prices will impound good (bad) news on the company's stock price with delay. In contrast to the previous cases, investors offer the immediate sale of shares which causes high or low pricing of shares. George and Hwang (2004) used the 52-week high prices and measure of nearness to the 52-week high as a predictor of return and anchoring bias, and the 52-week high as a measure of the environmental interaction and financial news of capital market brokers.

The importance of this ratio has been shown in different financial environments. The role of this ratio as a stimulus for investor behavior by four theories of anchoring behavior (Tversky and Kahneman, 1992), disposition effect (Shefrin and Statman, 1985), behavioral attention (Barber and Odean, 2007) and predictable errors (Biruu, 1985) are explained. Although it is not clear why individual investors are sensitive to a 52-week high price, George and Hwang (2004) showed that anchoring at the 52-week high plays a key role in future returns and investor's behavior. The scientists found when stocks trade near the 52-week high, investors are less sensitive to positive information and more sensitive to negative information.

Jegadeesh and Titman (1993) noted that the 52-week high price ratio rather than the momentum of past returns is a very economically and statistically positive predictor of future returns. Baker et al. (2012) refer to the 52-week high price as the key to momentum and anchoring activities. Anchors exist in most capital markets. Numbers rounded in Bhattacharya and O'Hara's (2018) 
research and investors' purchase prices in Ben-David and Hirshleifer (2012) are examples of these anchors. The 52-week high as an anchor can reflect the disposition effect of individual investors to sell the winning stock and hold the losing stock (Shefrin and Statman, 1985). The 52-week high can serve as a maximum point of cumulative profit for investors. Thus, reaching 52-week high increases the probability of selling held assets. Barber and Odean (2007) examined the role of investors' attention in trading and stock returns. They found that individual investors have more tendencies to buy and sell stocks that have attracted the attention of investors.

Peng and Xiong (2006) explained that investors pay attention to anchors in their transactions. Therefore, the 52-week high as the clear portion of the information provided by most brokers and financial news sources is expected to have a significant effect on future returns, the same as volume and trade imbalance. Blau et al (2018) documented that the price skewness premiums disappear at the highest price of 52 weeks because investors think that the highest price of 52 weeks is the highest level for stock returns. Therefore, investors are expected to raise the stock price by incorrectly predicting the future stock price path and untimely classification of these stocks for sale. Chen and Yang (2016) conducted research on anchoring at a 52-week high and momentum profit. They believed that investors consider their profit is in trading at the highest price of 52 weeks and therefore react to this price, which leads to increasing momentum profit.

Hur and Singh (2019) examined the Joint effect of anchoring on the 52week high and the disposition effect on momentum profit when the two biases reinforce each other and stocks had low liquidity; they find that momentum profit increased. The liquidity in the 52-week high is not very clear, and there are two perspectives about it. First, if individual investors desire to gain liquidity at the 52-week high price, considering their tendency to disposition effect, liquidity will be decreased. Because these investors seek to coordinate opposite parts. These results are consistent with Bian et al. (2018), who stated that investors are less interested in using limit orders to sell winner stocks. Second, Barber and Odean (2007) believe that liquidity at the highest price of 52 weeks increases for a short period because investors trade at anchored prices. Studies about the diversity and classification of stock liquidity levels are relatively limited. There are various reasons stated for the effect of the 52-week high prices, which are the primary basis for the behavior of individual investors. These key explanations are related to the disposition effect, anchoring bias, and the expected errors. First, similar to studies of An (2016), Grinblatt and Han (2005), Hur et al. (2010), and Wang (2017), nearness to the 
52-week high price can be a level of capital gains that shareholders hold every time. Increasing capital gains lead to making sales decisions among individual investors, especially the investors who are influenced by a disposition effect. These investors are interested in selling their stock at a price near to a 52-week high price. Because these stocks are in the range of investors' profits according to prospect theory performance. Second, when the price reaches to 52-week high price can be a key to grab the anchor (Aragon, Dieckmann, 2011 and Yuan, 2015).

Huddart et al. (2009) found that stock trading volume significantly increases when the price rises above the 52-week high. This increase is higher for smaller stocks and stocks with uncertain value or owned by individual holdings. Tversky and Kahneman (1974) suggested that in this situation where there are uncertain problems, people are interested in relying on discoveries, including anchors.

Daniel et al. (1998) stated that behavioral bias intensifies uncertainty status. Peng and Xiong (2006) stated since the 52-week high reported by brokers, and news agencies is an important anchor for investors' stock trading, it can be concluded that nearness to the 52-week high price causes the sale of stocks that has a deeply uncertain price. Third, the expectation error may be amplified at the 52-week high (Baker et al., 2012 and Biruu et al., 2015). Because of price targets and forecasting unexpected returns, analysts' and investors' expected returns decrease close to the 52-week high, so investors may prefer to sell their stocks near the 52-week high. Because they believe that future stock returns are likely to be lower, according to analysts. It is argued that unlike trading far from the 52-week high, trading close to the 52-week high price has no different premium skewness (Blau et al., 2018).

Momentum strategy uses the fundamental principles of physics and psychology. Based on this strategy, if the behavior of stock is examined systematically, the future stock prices id predictable. Driehaus (1980) first introduced the momentum strategy to the financial markets as a practical strategy. He believed that instead of buying an asset at a low price and waiting to raise its price, it is better to buy at a high price and sell it at a higher price to make. He believed the losing sellers would flatten the way for winning buyers. Later, the technique he used became the principle that today we know as momentum strategy (Clement, 2021). Momentum strategy involves investing in the trend of the market and claiming the negative or positive profit of momentum in the past will be extended in a certain period of future. Momentum includes different types. Based on momentum profit, it is argued that tocks whit increasing earnings per share will have good returns in the near 
future. Industry momentum claims industries that have good (bad) performance and returns recently, their performance will continue in the future (Brown and Martin, 2008). Another type of momentum is price momentum, in which stocks based on relative strength index perform better than others in the past and are held for a certain period. Prior studies based on this approach found that investors can earn excess returns (Grinblatt and Titman, 1989) .Behavioral models of some researchers such as George and Hwang (2004) are based on this approach states the momentum profit is due to the bias in the way investors interpret information. Momentum is a phenomenon that predicts future returns based on past returns.

Jegadeesh and Titman (1993) were the first to discover the ability of past returns to predict future returns. They generate a zero cost long-short momentum strategy, in which if they buy the $30 \%$ of the stock with the highest returns during the past six months and sell the $30 \%$ of stocks with the lowest returns during the past six months; they likely earn continuously zero cost returns about one percent per month during the following six months. Momentum is a dominant characteristic of cash markets. Griffin et al (2003) investigate the role of momentum in global markets. The findings of their research show that momentum can be a predictor of economic value and accurate return. Chui et al. (2010) and Asness et al. (2013) proved the presence of momentum in different assets, countries and measurement periods. Fama and French (2012) continued their global market research and stated that momentum in the worldwide market is a better predictor than individual stock predictors in countries.

Asness et al (2013) examined momentum in stock mispricing, stock market futures index, government securities, currencies, and futures trading. They found that momentum in the capital market could be the basis for future research to clarify that the momentum accrued due to rational reasons or investor behavior or a combination of them. Following Thaler and Bernartzi (1985), Jegadeesh and Titman (1993) indicated that long-term overreactions to information cause the stock prices to be higher than fair value. The logical model of Tversky and Kahneman (1974) shows that self-assertion and conservatism lead people to expect high-yield stocks and continue their performance. Therefore, investors believe that stock prices should be increased. Raising the stock price can cause momentum. There is a piece of important evidence to explain the potential sources of momentum. The first evidence of cross-sectional dispersion in expected returns in risky stocks is that it operates well over a period and continues to perform well. It is also addressed by controlling risk factors in the capital asset pricing model proposed by Sharpe 
(1964). Unlike the studies on cross-sectional dispersions in risk, Fama, French and Jegadeesh and Titman (2001) explain the presence of momentum by threefactor regression. Many researchers have tried to explain the momentum as the over and under the reaction of investors to the news. Hang and Stein (1999) stated that the information due to the investors' reaction to the news creates a slow flow of information in the market-leading to continuity of returns for six months. Hong et al. (2000) found that momentum is explained better among small stocks with less capital market participation. Grinblatt and Han (2005) found that the momentum arises from the disposition effect proposed by Shefrin and Statman (1985). The findings of their study show that investors sell stocks that have accumulated capital gains and it can lead to positive news then stocks prices will change more slowly during the holding period. These explanations show that investors with a disposition effect and mental accounting own a large part of the stock.

Many financial studies have shown that different variables affect the momentum profitability strategy such as liquidity and stock volume. The reason for different definitions of liquidity in the financial literature is different aspects of liquidity. Liquidity can be defined in three dimensions: time, price and trading volume. In respect of time, if a transaction with a dominant price can be done immediately, stock liquidity is high. In respect of price, liquidity means that consequent transactions (sale and purchase) occur with the same price. The third dimension of liquidity is trading volume, Meaning that the more trading volume of stock the higher the stock liquidity (Zamani and Faghani 2016). Aitken and Winn (1997) categorized the existing criteria for measuring liquidity into two areas; high frequency and low frequency. Highfrequency is defined as a measure that use information about all day-to-day transactions to calculate daily stock liquidity. Low-frequency measures stock liquidity using daily data.

Literature and researchers' findings on the effect of liquidity on momentum profit are not present separately. Chan et al. (2000) examined momentum strategy across the global stock market index and found that there is a consistent effect of momentum in the global market. Findings of prior studies documented that the persistence of returns has occurred with increasing trading volume in previous periods. These studies indicated that the return on momentum strategy in many cases depends on market liquidity. Sadka (2006) emphasized that considering liquidity as a factor to clarify momentum profits requires high value and trading volume. He also argues that a variety of liquidity helps to explain in detail, momentum profit strategy and stock price. The momentum strategy performs better when liquidity is positive. Korajczyk 
and Sadka (2004) found that momentum strategies are less profitable in large mutual funds. But if the structure of portfolios is designed based on liquidity, it is possible to earn profit. Pastor and Stambaugh (2003) found that the liquidity expansion explains half of the excess returns from the momentum portfolio. Lee and Swaminathan (2000) stated that the extra profit of the momentum strategy is greater in the higher volume of stock trading. Their findings are consistent with Sadka (2006). Chen et al. (2010) examined liquidity as an investment method. They found that stock portfolio with low liquidity performs better than portfolios with high liquidity. In addition, they examined the combined effect of liquidity and momentum strategy and concluded that high momentum in the portfolios with low liquidity had the highest returns in the samples, and investors hedge liquidity risk even though they adopt a momentum strategy.

\section{Research background}

Ahmed and Doukas (2021), in a study entitled "Revisiting disposition effect and momentum: a quantile regression perspective" examine the relationship between the unrealized capital gains and expected returns and capability of disposition effect as one of the underreaction models in inducing momentum in the most extreme quantiles $(0.05$ th and 0.95 th) of expected returns. They find when the expected return is less than $5 \%$, the disposition effect does not cause momentum. While the expected returns are above $95 \%$, the disposition effect causes momentum.

Chi Hsu and Chian (2020) examined the effect of anchoring bias on the profitability of the momentum time series on the NYSE, AMEX, and NASDAQ stock exchanges from January 1964 to December 2018. Their findings showed that the momentum strategy becomes more profitable as it approaches the 52-week high, and investors, due to the anchoring bias in response to positive information, are reluctant to raise prices.

Hur and Singh (2019), in a study entitled "How do disposition effect and anchoring bias interact to impact momentum in stock returns?" examined the impact of dispassion effect and anchoring bias on momentum profit. They showed when disposition effect and anchoring bias reinforce each other, and stocks have low liquidity, momentum profits increase.

Blau et al. (2020), in a study entitled "Does Probability Weighting Drive Lottery Preferences?" examined investors' preferences for positive skewness in return distributions. They used the well-documented 52-week high bias as a 
method to truncate investors' weighted probability of expected right-tail events. They found some pieces of evidence supporting the theoretical framework of Barberis and Huang as the negative return premiums associated with the positive skewness are driven almost entirely by stocks that are farther away from their 52-week high. No negative premiums related to skewness are detected when stock prices are close to the 52-week high.

Hao et.al. (2016), in a study entitled "The 52-week high and momentum in the Taiwan stock market: Anchoring or recency biases?" examined the role of the 52-week high in explaining momentum profits in the Taiwan stock market by comparing two strategies that are related to anchoring and recency biases, respectively. They showed that the profitability of the 52-week high strategy is attenuated by the considerably negative returns in the January months, while the profitability of the recency strategy is not sensitive to the January seasonality. However, the recency strategy still displays predictable time-series patterns when conditioning variables are taken into consideration. It is profitable only during periods before 2000 .

Badri and Fath Elahi (2014), in a sample of 94 companies of the Tehran Stock Exchange, showed that momentum-based trading strategies are profitable over the medium term. Fama and French's (1993) three-factor risk model cannot explain the momentum until the medium term and the momentum excess returns after risk control is a challenge to the market efficiency hypothesis. Therefore, the momentum of returns up to the mediumterm can be explained through behavioral models, and market volatility can create momentum. But in the long - time, the momentum of returns disappears.

Auret and Page (2013), examined the effect of liquidity on the momentum strategy in the Johannesburg Stock Exchange. They showed that portfolios with high and medium liquidity in terms of net return perform better than the portfolio with low liquidity, and Illiquidity has a significant negative effect on momentum profit. They believe when there is a pressure of positive news in the market, demand for high-momentum stocks will rise and high-liquidity stocks are quickly bought and their prices will rise. Likewise, when the market reacts strongly and stocks are buying too much, highly liquid stocks experience longterm prices. These findings indicate that in the momentum strategy, high and medium liquidity lead to significantly higher returns and the results of the momentum strategy with low liquidity have no significant returns.

\section{Research Hypotheses}

According to the theoretical foundations, the research hypotheses are presented 
as follows:

Hypothesis 1: The disposition effect in stocks with low liquidity, increases momentum profit.

Hypothesis 2: Anchoring bias in stocks with low liquidity, increases momentum profit.

Hypothesis 3: When the anchoring bias and the disposition effect reinforce each other, momentum profit increases

Hypothesis 4: When the anchoring bias and the disposition effect reinforce each other, momentum profit increases for the stocks with less liquidity.

\section{Research Methodology}

The purpose of this research is applied, its nature is descriptive-correlation, the data type is documentary, and execution time is post-event. The data required to test the hypotheses were collected through the audited financial statements of companies listed on the Tehran Stock Exchange (TSE) and stock price and volume information through the information system of publishers and Tehran Securities Exchange Technology Management Company and Rahavard Novin software.

The population of this study consists of all companies listed on TSE during the years 2007 to 2020 . Using the statistical sample selected by the systematic elimination method, the final sample consists of 136 companies. This study uses the following conditions to choose companies:

- The company was listed on TSE before 2007.

- The company has not been removed from TSE until the end of 2020.

- To increase the comparability, their fiscal year ends on March 31.

- Banks, investments and leasing companies are excluded from the sample.

- In the financial year, their stock trading has not stopped for more than three months.

- The required data of the company is available.

To test the research hypotheses, this study uses four multivariate regressions. Then the Fama-French five-factor models as a sensitivity analysis are used.

Models (1), (2), (3) and (4) are as follows: 


$$
\begin{aligned}
& R_{\mathrm{i}, \mathrm{t}}=\lambda_{0, t}+\lambda_{2, t} C G O_{i, t}+\lambda_{3, t} \operatorname{ILLIQ}_{i, t}+\lambda_{5, t} C G O_{i, t} * I L L I Q_{i, t}+\lambda_{6, t} I V O L_{i, t} \\
& +\lambda_{7, t} \operatorname{SIZE}_{i, t}+\lambda_{8, t} B E T A_{i, t}+\lambda_{9, t} B T M_{i, t}+\varepsilon_{i, t} \\
& \begin{array}{c}
R_{\mathrm{i}, \mathrm{t}}=\lambda_{0, t}+\lambda_{1, t} G_{i, t}+\lambda_{3, t} I_{L L I Q_{i, t}}+\lambda_{4, t} G H_{i, t} * I L L I Q_{i, t}+\lambda_{6, t} I V O L_{i, t} \\
+\lambda_{7, t} \operatorname{SIZE}_{i, t}+\lambda_{8, t} B E T A_{i, t}+\lambda_{9, t} B T M_{i, t}+\varepsilon_{i, t}
\end{array}
\end{aligned}
$$

$\mathrm{R}_{\mathrm{i}, \mathrm{t}}=\lambda_{0}+\lambda_{1} \mathrm{GH}_{\mathrm{i}, \mathrm{t}}+\lambda_{2} \mathrm{CGO}_{\mathrm{i}, \mathrm{t}}+\lambda_{3} \mathrm{GH}_{\mathrm{i}, \mathrm{t}} * \mathrm{CGO}_{\mathrm{i}, \mathrm{t}}+\lambda_{4} \mathrm{IVOL}_{\mathrm{i}, \mathrm{t}}+\lambda_{5} \mathrm{SIZE}_{\mathrm{i}, \mathrm{t}}+$ $\lambda_{6}$ BETA $_{i, t}+\lambda_{7}$ BTM $_{i, t}+\varepsilon_{i, t}$

$$
\begin{array}{rl}
R_{\mathrm{i}, \mathrm{t}}=\lambda_{0}+\lambda_{1} & G H_{i, t}+\lambda_{2} C G O_{i, t}+\lambda_{3} I_{L L I Q_{i, t}}+\lambda_{4} G H_{i, t} * C G O_{i, t}+\lambda_{5} G H_{i, t} \\
& * I_{L L I Q_{i, t}}+\lambda_{6} C G O_{i, t} * I L L I Q_{i, t}+\lambda_{7} G H_{i, t} * C G O_{i, t} * I L L I Q_{i, t} \\
& +\lambda_{8} I V O L_{i, t}+\lambda_{9} \operatorname{SIZE}_{i, t}+\lambda_{10} \text { BETA }_{i, t}+\lambda_{11} B_{i, t}+\varepsilon_{i, t}
\end{array}
$$

The dependent variable of this research is momentum profit, which is measured using the methodology of Jegadeesh and Titman (1993). Momentum profit in the present study is calculated in three modes: quarterly momentum, six-month momentum, and nine-month momentum $\left(R_{i, \mathrm{t}}\right)$, equals to stock returns in quarterly, six-month and nine-month periods. The independent variables of the research are disposition effect (CGO), anchorage bias (GH) and stock liquidity (LIQ), which are described below.

\section{Disposition effect (CGO)}

To calculate the disposition effect, following Grinblatt and Han (2005) and Frazzini (2006), this study uses the capital gains overhang pattern of each share. To this purpose, to calculate the reference price for each share at the end of each month, the daily data of five years ago and the following formula is used:

$R_{\mathrm{t}}=\frac{1}{\mathrm{k}} \sum_{\mathrm{n}=1}^{T}\left(\mathrm{~V}_{\mathrm{t}-\mathrm{n}} \prod_{\tau=1}^{\mathrm{n}-1}\left(1-\mathrm{V}_{\mathrm{t}-\mathrm{n}+\tau}\right)\right) \mathrm{P}_{\mathrm{t}-\mathrm{n}}$ 
$\mathrm{V}_{\mathrm{t}}$ is the turnover of stock transactions (i.e., the ratio of stock trading volume to the number of shares issued by the company) in week $t$. $T$ refers to the number of trading days during the last five years in which daily trading volume and stock price information was available. $\mathrm{P}_{\mathrm{t}-\mathrm{n}}$ is the stock price, and $\mathrm{K}$ is the constant coefficient that ensures the total weight of the sum reaches one. The weight $\mathrm{P}_{\mathrm{t}-\mathrm{n}}$ reflects the probability that the stock purchased on the date $\mathrm{t}-\mathrm{n}$ has not yet been traded. The pattern of capital gains overhang per share (disposition effect) at the end of month $\mathrm{t}$ is calculated as follows:

$C G O_{i t}=\frac{P_{t}-R_{t}}{P_{t}}$

$C G O_{i t}$ : Disposition effect of firm $\mathrm{i}$ in the month $\mathrm{t}$

$P_{t}$ : Stock market price of firm $\mathrm{i}$ in the month $\mathrm{t}$

\section{Anchoring bias (GH)}

This study uses the ratio of George and Hwang (2004) to calculate the anchorage bias. In this ratio, the criterion of nearness to the 52-week high price is used, which is calculated at the end of each month through the following relation:

$G H=\frac{\text { current stock price }}{52 \text { week high price }}$

According to George and Hwang (2004), a stock with high-GH has received good news in the market, and stock with low-GH has received bad news.

\section{Liquidity of stocks (LIQ)}

According to Amihud (2002), illiquidity is obtained from the ratio of the absolute value of the monthly stock return to the trade volume of that stock. If it is higher than median $I L L I Q_{i, t}$ takes a value of 1 and 0 otherwise.

Amihud ILLIQ $Q_{i, t}=\frac{\left|R_{i, t}\right|}{\operatorname{VOLD_{i,t}}}$

The control variables of this study are calculated as follows:

$I_{V O L}:$ Idiosyncratic volatility

$S I Z E_{i, t}:$ Firm size

$B E T A_{i, t}:$ Stock Beta 
$B T M_{i, t}$ : Book-to-Market ratio

For sensitivity analysis the Fama-French five-factor models is fitted as follows:

$$
\begin{aligned}
R_{p, t}-R_{f, t}= & \beta_{0}+\beta_{1}\left(R_{m, t}-R_{f, t}\right)+\beta_{2}\left(S M B_{t}\right)+\beta_{3}\left(H M L_{t}\right)+\beta_{4}\left(R M W_{t}\right) \\
& +\beta_{4}\left(C M A_{t}\right)+\varepsilon_{i, t}
\end{aligned}
$$

Market factor $\left(R_{m, t}-R_{f, t}\right)$ : This is calculated from the difference between market returns and risk-free returns. The risk-free return is equal to the interest rate on one-year bank deposits reported by the central bank.

Size Factor (SMB): Following Fama and French (1993), first, the firms are sorted by size at the end of each year and after calculating the median, the companies are divided into small and large groups. The size factor is then calculated from the difference between the average monthly return on the portfolio of small companies and the portfolio of large companies.

Value Factor (HML): According to Fama and French (1993), the firms are sorted by market value at the end of each year and the companies are divided into three groups. The value factor is then calculated from the difference between the average monthly return on the portfolio of $30 \%$ high-value companies and $30 \%$ low-value companies.

Operating profitability factor (RMW): Following the Fama and French (2015) model, at the end of each year, the sample firms are ranked according to the ratio of operating profit less interest expense to book value of equity. This variable is the difference between the average monthly return on a stock portfolio with high profitability and the average monthly return of a stock portfolio with low profitability.

Investment factor (CMA): This factor is obtained from the difference between the average monthly return on the portfolio of firms with low investment and the average monthly return on the portfolio of firms with high investment. The percentage of growth of the company's assets is used to calculate a firm's investment.

To test the first hypothesis, initially, the firms are divided into three groups 
per month based on disposition effect and each group is divided into three groups based on the illiquidity variable. Thus Nine 9 portfolios $(3 * 3)$ are created and then the average return of each portfolio is calculated and used as a dependent variable.

To test the second hypothesis, the firms are divided into three groups per month based on the anchoring bias and each group is divided into three groups based on the illiquidity variable. Thus, nine portfolios $(3 * 3)$ are created and then the average of each portfolio is calculated as a dependent variable.

Regarding the test of the third hypothesis, initially, the firms are grouped once based on the variable of disposition effect and again based on the variable of anchoring bias. Thus, nine portfolios are formed as $3 * 3$. After calculating the momentum yield average of each portfolio, the variable "A-B" is calculated. "A" refers to the difference between the average of the returns of portfolios with high disposition effect and high anchoring portfolio and the average of the returns of portfolios with low disposition effect and low anchor portfolio. "B" also refers to the difference between the average of the returns of portfolios with high disposition effect and low anchoring and the average of the returns of portfolios with low disposition effect and high anchoring.

Finally, to test the fourth hypothesis, first, stocks were divided into two groups based on the liquidity variable. Then, in each group, the stocks are divided once based on the variable disposition effect and again based on the anchoring variable. Therefore, nine portfolios as $3 * 3$ for the low liquidity group and nine as $3 * 3$ for the high liquidity group are created. Then, the average momentum yield of each portfolio (separately in the group of low liquidity and in the group of high liquidity) is calculated. Finally, the variable "A-B" is measured for each group. " $A$ " refers to the difference between the average of the returns of portfolios with high disposition effect and high anchoring and the average of the returns of portfolios with low disposition and low anchoring. "B" also refers to the difference between the average of the returns of portfolios with high disposition effect and low anchoring and the average of the returns of portfolios with low disposition effect and high anchoring. So, the research model is calculated separately in the group with low liquidity and again in the group with high liquidity and the results are 
interpreted. To test all four hypotheses, the intercept of the model has been analyzed. New-West adjusted was used to solve the problem of heterogeneity of variance and autocorrelation.

\section{Research Findings}

Before presenting the findings of inferential statistics, Table (1) shows the descriptive statistics of research variables.

Table 1. Descriptive statistics of variables

\begin{tabular}{|c|c|c|c|c|c|}
\hline Variable & Mean & Median & Maximum & Minimum & Std. Dev \\
\hline Ri (3) & 0.153 & 0.037 & 3.824 & -0.552 & 0.422 \\
\hline Ri (6) & 0.319 & 0.087 & 4.884 & -0.608 & 0.740 \\
\hline Ri (9) & 0.513 & 0.145 & 5.895 & -0.689 & 1.154 \\
\hline CGO & 0.218 & 0.259 & 0.946 & -1.442 & 0.352 \\
\hline GH & 1.001 & 0.993 & 1.722 & 0.001 & 0.083 \\
\hline IVOL & 0.103 & 0.102 & 0.185 & 0.054 & 0.104 \\
\hline SIZE & 12.724 & 12.692 & 19.727 & 6.483 & 2.168 \\
\hline BETA & 0.754 & 0.556 & 1.214 & 0.271 & 0.802 \\
\hline BTM & 0.569 & 0.483 & 0.824 & 0.267 & 0.437 \\
\hline Rp-Rf (3) & 0.114 & 0.024 & 1.334 & -0.264 & 0.249 \\
\hline Rp-Rf (6) & 0.242 & 0.068 & 3.476 & -0.355 & 0.479 \\
\hline Rp-Rf (9) & 0.399 & 0.101 & 4.183 & -0.432 & 0.768 \\
\hline Rm-Rf & 0.018 & 0.003 & 0.247 & -0.101 & 0.066 \\
\hline SMB & -0.000 & -0.004 & 0.092 & -0.071 & 0.032 \\
\hline HML & -0.038 & -0.035 & 0.166 & -0.222 & 0.053 \\
\hline RMW & 0.000 & 0.001 & 0.118 & -0.107 & 0.045 \\
\hline CMA & 0.004 & 0.002 & 0.161 & -0.104 & 0.044 \\
\hline & & Source: Research Findings & & \\
\hline
\end{tabular}

Descriptive statistics show the mean of excess portfolio risk that indicates the difference between stock returns and risk-free rates are 0.114 in three-month, 0.242 in six-month and, 0.399 in nine-month periods.

The first hypothesis states that the disposition effect in stocks with low 
liquidity increases momentum profit. Table (2) shows the regression results for the disposition effect in stocks with low liquidity on momentum profit.

Table 2. Regression results for the disposition effect in stocks with low liquidity on momentum profit

\begin{tabular}{|c|c|c|c|c|c|c|c|c|c|}
\hline \multicolumn{10}{|c|}{ 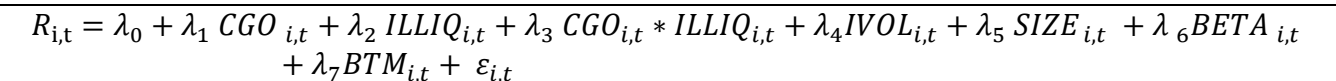 } \\
\hline \multicolumn{4}{|c|}{3 months momentum } & \multicolumn{3}{|c|}{6 months momentum } & \multicolumn{3}{|c|}{9 months momentum } \\
\hline Variable & $\begin{array}{c}\text { Coefficie } \\
\text { nt }\end{array}$ & $\begin{array}{c}\mathrm{t}- \\
\text { Statisti } \\
\mathrm{c}\end{array}$ & Prob & $\begin{array}{c}\text { Coefficie } \\
\text { nt }\end{array}$ & $\begin{array}{c}\mathrm{t}- \\
\text { Statisti } \\
\mathrm{c}\end{array}$ & Prob & $\begin{array}{c}\text { Coefficie } \\
\text { nt }\end{array}$ & $\begin{array}{c}\mathrm{t}- \\
\text { Statisti } \\
\mathrm{c}\end{array}$ & Prob \\
\hline $\mathrm{C}$ & 0.141 & 34.222 & 0.000 & 0.599 & 61.968 & $\begin{array}{c}0.00 \\
0\end{array}$ & 1.252 & 80.331 & $\begin{array}{c}0.00 \\
0\end{array}$ \\
\hline CGO & 0.000 & 0.049 & 0.961 & 0.000 & 0.098 & $\begin{array}{c}0.92 \\
2\end{array}$ & 0.066 & 16.787 & $\begin{array}{c}0.00 \\
0\end{array}$ \\
\hline ILLIQ & 0.002 & 4.350 & 0.000 & 0.012 & 17.880 & $\begin{array}{c}0.00 \\
0\end{array}$ & 0.005 & 5.293 & $\begin{array}{c}0.00 \\
0\end{array}$ \\
\hline $\begin{array}{l}\text { CGO*ILL } \\
\text { IQ }\end{array}$ & 0.028 & 21.400 & 0.000 & 0.008 & 4.829 & $\begin{array}{c}0.00 \\
0\end{array}$ & 0.059 & 24.145 & $\begin{array}{c}0.00 \\
0\end{array}$ \\
\hline IVOL & 0.009 & 4.926 & 0.000 & 0.003 & 1.422 & $\begin{array}{c}0.15 \\
5\end{array}$ & 0.009 & 2.451 & $\begin{array}{c}0.01 \\
4\end{array}$ \\
\hline SIZE & 0.001 & 3.350 & 0.001 & -0.023 & -31.271 & $\begin{array}{c}0.00 \\
0\end{array}$ & -0.056 & -47.034 & $\begin{array}{c}0.00 \\
0\end{array}$ \\
\hline BETA & -0.000 & -1.357 & 0.175 & -0.000 & -.964 & $\begin{array}{c}0.33 \\
5\end{array}$ & -0.001 & -4.805 & $\begin{array}{c}0.00 \\
0\end{array}$ \\
\hline BTM & -014 & -11.601 & $\begin{array}{c}0.000 \\
0 \\
\end{array}$ & 0.032 & 14.985 & $\begin{array}{c}0.00 \\
0 \\
\end{array}$ & -0.002 & -.587 & $\begin{array}{c}0.55 \\
7 \\
\end{array}$ \\
\hline $\operatorname{AR}(1)$ & 0.691 & $\begin{array}{c}1421.8 \\
11\end{array}$ & 0.000 & 0.838 & $\begin{array}{c}2278.5 \\
08\end{array}$ & $\begin{array}{c}0.00 \\
0\end{array}$ & 0.854 & $\begin{array}{c}2444.3 \\
66\end{array}$ & $\begin{array}{c}0.00 \\
0\end{array}$ \\
\hline \multicolumn{2}{|c|}{ F-statistic } & \multicolumn{2}{|c|}{253368.9} & \multicolumn{3}{|c|}{652563.9} & \multicolumn{3}{|c|}{763550.6} \\
\hline \multicolumn{2}{|c|}{ Prob (F-statistic) } & \multicolumn{2}{|c|}{0.000} & \multicolumn{3}{|c|}{0.000} & \multicolumn{3}{|c|}{0.000} \\
\hline \multicolumn{2}{|c|}{ Adjusted R- squared } & \multicolumn{2}{|c|}{0.479} & \multicolumn{3}{|c|}{0.703} & \multicolumn{3}{|c|}{.735} \\
\hline \multicolumn{2}{|c|}{ Durbin-Watson stat } & \multicolumn{2}{|c|}{1.626} & \multicolumn{3}{|c|}{1.772} & \multicolumn{3}{|c|}{1.817} \\
\hline
\end{tabular}

According to Table (2), the interaction coefficient of illiquidity and disposition effect in the three-month, six-month, and nine-month periods are $0.028,0.008$, and 0.059 , respectively. They are significant at a $1 \%$ level of significance in all three periods. While the interaction between illiquidity and disposition effect is significant, it can be said that the disposition effect in stocks with low liquidity increases the momentum profit in all three cases of three-month momentum, six-month momentum, and nine-month momentum. These findings support hypothesis 1 . The F-statistic of the models is 253368.9, 652563.9 and 763550.6 for three-month momentum, six-month momentum, and nine-month momentum, respectively. They are significant at a $1 \%$ level of 
significance. The adjusted R- squared in the three models is $0.479,0.703$, and 0.735 , respectively.

The second hypothesis states that the anchoring bias in stocks with low liquidity increases momentum profit. Table (3) shows the regression results for the anchoring bias in stocks with low liquidity on momentum profit.

Table 3. Regression results for the effect of anchoring bias in stocks with low liquidity on momentum profit

\begin{tabular}{|c|c|c|c|c|c|c|c|c|c|}
\hline \multicolumn{8}{|c|}{$R_{\mathrm{i}, \mathrm{t}}=\lambda_{0}+\lambda_{1} G H_{i, t}+\lambda_{2} I L L I Q_{i, t}+\lambda_{3} G H_{i, t} * I L L I Q_{i, t}+\lambda_{4} I V O L_{i, t}+\lambda_{5} S I Z E_{i, t}$} \\
$+\lambda_{6} B_{2 T A}+\lambda_{i, t}+\lambda_{7} B T M_{i, t}+\varepsilon_{i, t}$
\end{tabular}

According to the contents of Table (3), the interaction coefficient of illiquidity and anchoring bias in the three-month, six-month, and nine-month periods is $0.094,0.059$, and 0.014 respectively. They are significant at a $1 \%$ level of significance in the two periods of three-month and six-month and at a $10 \%$ level of significance in the nine months. Since these findings support 
hypothesis 2. The F-statistic of the models in all three modes is 253415.0, 653044.7, and 763000.0, respectively. They are significant at a $1 \%$ level of significance. The adjusted R- squared in the three cases is $0.479,0.703$, and 0.735 , respectively.

The third hypothesis states that the interaction term of the anchoring bias and the disposition effect may increase momentum profits. Table (4) shows the regression results for the effect of the anchoring bias and the disposition effect on momentum profit.

Table 4. Regression results for the effect of the anchoring bias and the disposition effect on momentum profit

\begin{tabular}{|c|c|c|c|c|c|c|c|c|c|}
\hline \multicolumn{10}{|c|}{$\begin{array}{c}\mathrm{R}_{\mathrm{i}, \mathrm{t}}=\lambda_{0}+\lambda_{1} \mathrm{GH}_{\mathrm{i}, \mathrm{t}}+\lambda_{2} \mathrm{CGO}_{\mathrm{i}, \mathrm{t}}+\lambda_{3} \mathrm{GH}_{\mathrm{i}, \mathrm{t}} * \mathrm{CGO}_{\mathrm{i}, \mathrm{t}}+\lambda_{4} \mathrm{IVOL}_{\mathrm{i}, \mathrm{t}}+\lambda_{5} \mathrm{SIZE}_{\mathrm{i}, \mathrm{t}}+\lambda_{6} \mathrm{BETA}_{\mathrm{i}, \mathrm{t}} \\
+\lambda_{7} \mathrm{BTM}_{\mathrm{i}, \mathrm{t}}+\varepsilon_{\mathrm{i}, \mathrm{t}}\end{array}$} \\
\hline \multicolumn{4}{|c|}{3 months momentum } & \multicolumn{3}{|c|}{6 months momentum } & \multicolumn{3}{|c|}{9 months momentum } \\
\hline $\begin{array}{l}\text { Variabl } \\
\text { e }\end{array}$ & $\begin{array}{l}\text { Coeffici } \\
\text { ent }\end{array}$ & $\begin{array}{c}\mathrm{t}- \\
\text { Statist } \\
\text { ic }\end{array}$ & $\begin{array}{c}\text { Pro } \\
b\end{array}$ & $\begin{array}{l}\text { Coeffici } \\
\text { ent }\end{array}$ & $\begin{array}{c}\mathrm{t}- \\
\text { Statisti } \\
\mathrm{c}\end{array}$ & Prob & $\begin{array}{l}\text { Coeffici } \\
\text { ent }\end{array}$ & $\begin{array}{c}\mathrm{t}- \\
\text { Statisti } \\
\mathrm{c}\end{array}$ & $\begin{array}{c}\text { Pro } \\
\mathrm{b}\end{array}$ \\
\hline $\mathrm{C}$ & 0.066 & $\begin{array}{c}13.93 \\
9\end{array}$ & $\begin{array}{c}0.00 \\
0\end{array}$ & 0.707 & 69.422 & $\begin{array}{c}0.00 \\
0\end{array}$ & 1.173 & 72.311 & $\begin{array}{c}0.00 \\
0\end{array}$ \\
\hline GH & 0.073 & $\begin{array}{c}27.98 \\
7\end{array}$ & $\begin{array}{c}0.00 \\
0\end{array}$ & 0.132 & 39.278 & $\begin{array}{c}0.00 \\
0\end{array}$ & 0.056 & 11.322 & $\begin{array}{c}0.00 \\
0\end{array}$ \\
\hline $\mathrm{CGO}$ & 0.022 & $\begin{array}{c}14.01 \\
6\end{array}$ & $\begin{array}{c}0.00 \\
0\end{array}$ & 0.049 & 18.115 & $\begin{array}{c}0.00 \\
0\end{array}$ & 0.112 & 27.057 & $\begin{array}{c}0.00 \\
0\end{array}$ \\
\hline $\begin{array}{l}\mathrm{GH}^{*} \mathrm{C} \\
\mathrm{GO}\end{array}$ & 0.023 & $\begin{array}{c}21.65 \\
0\end{array}$ & $\begin{array}{c}0.00 \\
0\end{array}$ & 0.019 & 0.001 & $\begin{array}{c}0.00 \\
0\end{array}$ & 0.004 & 1.959 & $\begin{array}{c}0.05 \\
0\end{array}$ \\
\hline IVOL & 0.000 & 0.295 & $\begin{array}{c}0.76 \\
8\end{array}$ & 0.025 & 9.952 & $\begin{array}{c}0.00 \\
0\end{array}$ & -0.006 & -1.755 & $\begin{array}{c}0.07 \\
9\end{array}$ \\
\hline SIZE & 0.002 & 5.928 & $\begin{array}{c}0.00 \\
0\end{array}$ & -0.023 & $\begin{array}{c}- \\
31.143\end{array}$ & $\begin{array}{c}0.00 \\
00\end{array}$ & -0.054 & 45.183 & $\begin{array}{c}0.00 \\
0\end{array}$ \\
\hline BETA & -0.000 & -2.072 & $\begin{array}{c}0.03 \\
8 \\
\end{array}$ & -0.000 & -0.414 & $\begin{array}{c}0.67 \\
9 \\
\end{array}$ & -0.000 & -5.070 & $\begin{array}{c}0.00 \\
0 \\
\end{array}$ \\
\hline BTM & -0.017 & $\begin{array}{c}- \\
13.46 \\
9\end{array}$ & $\begin{array}{c}0.00 \\
0\end{array}$ & 0.036 & 17.136 & $\begin{array}{c}0.00 \\
0\end{array}$ & -0.004 & -1.331 & $\begin{array}{c}0.18 \\
3\end{array}$ \\
\hline $\operatorname{AR}(1)$ & 0.691 & $\begin{array}{c}142.9 \\
24\end{array}$ & $\begin{array}{c}0.00 \\
0\end{array}$ & 0.839 & $\begin{array}{c}2287.1 \\
81\end{array}$ & $\begin{array}{c}0.00 \\
0\end{array}$ & 0.854 & $\begin{array}{c}2442.7 \\
04\end{array}$ & $\begin{array}{c}0.00 \\
0\end{array}$ \\
\hline \multicolumn{2}{|c|}{ F-statistic } & \multicolumn{2}{|c|}{253467.4} & \multicolumn{3}{|c|}{653076.6} & \multicolumn{3}{|c|}{763222.2} \\
\hline \multicolumn{2}{|c|}{ Prob (F-statistic) } & \multicolumn{2}{|c|}{0.000} & \multicolumn{3}{|c|}{0.000} & \multicolumn{3}{|c|}{0.000} \\
\hline \multicolumn{2}{|c|}{ Adjusted R-squared } & \multicolumn{2}{|c|}{0.479} & \multicolumn{3}{|c|}{0.703} & \multicolumn{3}{|c|}{0.735} \\
\hline \multicolumn{2}{|c|}{ Durbin-Watson stat } & 1.62 & .707 & & 1.773 & & & 1.817 & \\
\hline \multicolumn{10}{|c|}{ Source: Research Findings } \\
\hline
\end{tabular}

The interaction coefficient of anchoring bias and the disposition effect in 
the three-month, six-month and nine-month momentum is $0.023,0.019$, and 0.004 , respectively. They are significant at a 5\% level of significance These findings support hypothesis 3 which shows when the anchoring bias and the disposition effect reinforce each other, they can increase the momentum profit. The F-statistic in all three cases of three-month momentum, six-month momentum, and nine-month momentum is 253467.4, 653076.6 and 763222.2, respectively, they are significant at a $5 \%$ level of significance. The adjusted Rsquared in the three cases is $0.479,0.703$ and 0.735 , respectively.

The fourth hypothesis states that the interaction term of the anchoring bias and the disposition effect may increase the momentum profit for the stocks with less liquidity. Table (5) shows the regression results for the effect of the anchoring bias and the disposition effect on the momentum profit for the stocks with less liquidity.

Table 5. Results of testing the forth research hypothesis

\begin{tabular}{|c|c|c|c|c|c|c|c|c|c|}
\hline \multicolumn{10}{|c|}{$\begin{array}{c}R_{\mathrm{i}, \mathrm{t}}=\lambda_{0}+\lambda_{1} G H_{i, t}+\lambda_{2} C G O_{i, t}+\lambda_{3} I_{L L I Q_{i, t}}+\lambda_{4} G H_{i, t} * C G O_{i, t}+\lambda_{5} G H_{i, t} * I L L I Q_{i, t} \\
+\lambda_{6} C G O_{i, t} * I L L I Q_{i, t}+\lambda_{7} G H_{i, t} * C G O_{i, t} * I L L I Q_{i, t}+\lambda_{8} I V O L_{i, t} \\
+\lambda_{9} S_{i Z E_{i, t}}+\lambda_{10} B E T A_{i, t}+\lambda_{11} B T M_{i, t}+\varepsilon_{i, t}\end{array}$} \\
\hline \multicolumn{4}{|c|}{3 months momentum } & \multicolumn{3}{|c|}{6 months momentum } & \multicolumn{3}{|c|}{9 months momentum } \\
\hline $\begin{array}{l}\text { Variabl } \\
\mathrm{e}\end{array}$ & $\begin{array}{c}\text { Coeffic } \\
\text { ient }\end{array}$ & $\begin{array}{l}\text { t- } \\
\text { Statisti } \\
\text { c }\end{array}$ & Prob & $\begin{array}{c}\text { Coeffi } \\
\text { cient }\end{array}$ & $\begin{array}{l}\text { t- } \\
\text { Statisti } \\
\quad c\end{array}$ & Prob & $\begin{array}{l}\text { Coeffi } \\
\text { cient }\end{array}$ & $\begin{array}{l}\mathrm{t}- \\
\text { Statisti } \\
\mathrm{c}\end{array}$ & Prob \\
\hline $\mathrm{C}$ & 0.046 & 9.222 & 0.000 & 0.738 & 71.142 & 0.000 & 1.226 & 74.398 & 0.000 \\
\hline $\mathrm{CGO}$ & 0.012 & 6.808 & 0.000 & 0.044 & 15.598 & 0.000 & 0.088 & 20.528 & 0.000 \\
\hline GH & 0.981 & 32.452 & 0.000 & 0.149 & 38.662 & 0.000 & $\begin{array}{c}0.033 \\
7 \\
\end{array}$ & 5.967 & 0.000 \\
\hline ILLIQ & 0.077 & 16.946 & 0.000 & 0.065 & 11.634 & 0.000 & 0.075 & 9.155 & 0.000 \\
\hline $\begin{array}{c}\mathrm{GH} * \mathrm{CG} \\
\mathrm{O}\end{array}$ & 0.0234 & 1.631 & 0.095 & 0.019 & 13.943 & 0.000 & 0.003 & 1.648 & 0.099 \\
\hline $\begin{array}{l}\text { GH* } \\
\text { ILLIQ }\end{array}$ & 0.076 & 16.607 & 0.000 & 0.055 & 9.665 & 0.000 & 0.071 & 8.542 & 0.000 \\
\hline $\begin{array}{l}\text { CGO* } \\
\text { ILLIQ }\end{array}$ & 0.023 & 16.737 & 0.000 & 0.003 & 1.820 & 0.063 & 0.063 & 25.313 & 0.000 \\
\hline $\begin{array}{l}\mathrm{GH}^{* \mathrm{CG}} \\
\mathrm{O}^{*} \\
\text { ILLIQ }\end{array}$ & 2.693 & 1.221 & 0.182 & 6.265 & 1.587 & 0.113 & 5.137 & 1.394 & 0.163 \\
\hline IVOL & 0.010 & 5.0172 & 0.000 & 0.0187 & 7.212 & 0.000 & -0.013 & -3.471 & 0.000 \\
\hline SIZE & 0.001 & 3.915 & 0.000 & 0.0238 & -31.870 & 0.000 & $\begin{array}{c}- \\
0.056 \\
1\end{array}$ & -46.931 & 0.000 \\
\hline BETA & -0.000 & -1.033 & 0.302 & -0.000 & -0.879 & 0.379 & -0.001 & -5.324 & 0.000 \\
\hline BTM & -0.017 & -13.280 & 0.000 & 0.0359 & 16.903 & 0.000 & -0.004 & -1.300 & 0.194 \\
\hline $\mathrm{AR}(1)$ & 0.690 & $\begin{array}{c}142.01 \\
2\end{array}$ & 0.000 & 0.839 & $\begin{array}{c}2286.0 \\
37\end{array}$ & 0.000 & 0.854 & $\begin{array}{c}2441.4 \\
88\end{array}$ & 0.000 \\
\hline \multicolumn{2}{|c|}{ F-statistic } & \multicolumn{2}{|c|}{169106.3} & \multicolumn{3}{|c|}{435495.1} & \multicolumn{3}{|c|}{509114.5} \\
\hline \multicolumn{2}{|c|}{ Prob (F-statistic) } & \multicolumn{2}{|c|}{0.000} & \multicolumn{3}{|c|}{0.000} & \multicolumn{3}{|c|}{0.000} \\
\hline
\end{tabular}


Iranian Journal of Finance, 2021, Vol. 6, No. 1 (Soltani, F.)

\begin{tabular}{|cc|c|c|}
\hline Adjusted R- squared & 0.480 & 0.7036 & 0.735148 \\
\hline Durbin-Watson stat & 1.626 & 1.773 & 1.817 \\
\hline \multicolumn{4}{|c|}{ Source: Research Findings } \\
\hline
\end{tabular}

Based on Table (5), the interaction coefficient of the anchoring bias and the disposition effect in stocks with low liquidity in the three-month, six-month, and nine-month periods is $2.693,6.265$, and 5.137, respectively. They are not significant even at a $10 \%$ level of significance. Therefore, the fourth hypothesis is rejected.

As a sensitivity analysis, the disposition effect in stocks with low liquidity on the momentum profit is examined using the Fama-French five-factor models. Findings are presented in Table (6).

Table 6. Regression results for the disposition effect in stocks with low liquidity on momentum profit using the Fama-French model

\begin{tabular}{|c|c|c|c|c|c|c|c|c|c|}
\hline \multicolumn{10}{|c|}{$R_{p, t}-R_{f, t}=\beta_{0}+\beta_{1}\left(R_{m, t}-R_{f, t}\right)+\beta_{2}\left(S M B_{t}\right)+\beta_{3}\left(H M L_{t}\right)+\beta_{4}\left(R M W_{t}\right)+\beta_{4}\left(C M A_{t}\right)+\varepsilon_{i, t}$} \\
\hline \multicolumn{4}{|c|}{3 months momentum } & \multicolumn{3}{|c|}{6 months momentum } & \multicolumn{3}{|c|}{9 months momentum } \\
\hline $\begin{array}{c}\text { Variab } \\
\text { le }\end{array}$ & $\begin{array}{c}\text { Coefficie } \\
\text { nt }\end{array}$ & $\begin{array}{c}\mathrm{t}- \\
\text { Statist } \\
\text { ic } \\
\end{array}$ & Prob & $\begin{array}{c}\text { Coefficie } \\
\text { nt }\end{array}$ & $\begin{array}{c}\mathrm{t}- \\
\text { Statist } \\
\text { ic }\end{array}$ & Prob & $\begin{array}{c}\text { Coefficie } \\
\text { nt }\end{array}$ & $\begin{array}{c}\mathrm{t}- \\
\text { Statist } \\
\text { ic }\end{array}$ & Prob \\
\hline $\mathrm{C}$ & 0.107 & 6.224 & $\begin{array}{c}0.00 \\
0\end{array}$ & 0.231 & 4.406 & $\begin{array}{c}0.00 \\
0\end{array}$ & 0.378 & 4.116 & $\begin{array}{c}0.00 \\
0\end{array}$ \\
\hline $\mathrm{R}_{\mathrm{m}-} \mathrm{R}_{\mathrm{f}}$ & 0.186 & 2.424 & $\begin{array}{c}0.01 \\
5\end{array}$ & 0.247 & 2.194 & $\begin{array}{c}0.02 \\
8 \\
\end{array}$ & 0.798 & 4.124 & $\begin{array}{c}0.00 \\
0\end{array}$ \\
\hline SMB & -0.166 & -1.257 & $\begin{array}{c}0.20 \\
9\end{array}$ & -0.373 & -1.976 & $\begin{array}{c}0.03 \\
6\end{array}$ & -0.096 & -0.349 & $\begin{array}{c}0.72 \\
7\end{array}$ \\
\hline HML & -0.020 & -0.275 & $\begin{array}{c}0.78 \\
3\end{array}$ & -0.066 & -0.574 & $\begin{array}{c}0.56 \\
6\end{array}$ & 0.068 & 4.380 & $\begin{array}{c}0.00 \\
4\end{array}$ \\
\hline RMW & 0.055 & 0.588 & $\begin{array}{c}0.55 \\
6 \\
\end{array}$ & 0.154 & 1.394 & $\begin{array}{c}0.16 \\
4 \\
\end{array}$ & 0.149 & 0.822 & $\begin{array}{c}0.41 \\
1 \\
\end{array}$ \\
\hline CMA & 0.365 & 3.363 & $\begin{array}{c}0.00 \\
0 \\
\end{array}$ & 0.187 & 1.135 & $\begin{array}{c}0.25 \\
7 \\
\end{array}$ & 0.615 & 2.865 & $\begin{array}{c}0.00 \\
4 \\
\end{array}$ \\
\hline $\mathrm{AR}(1)$ & 0.737 & 32.545 & $\begin{array}{c}0.00 \\
0 \\
\end{array}$ & 0.856 & 40.239 & $\begin{array}{c}0.00 \\
0 \\
\end{array}$ & 0.871 & 32.061 & $\begin{array}{c}0.00 \\
0 \\
\end{array}$ \\
\hline \multicolumn{2}{|c|}{ F-statistic } & \multicolumn{2}{|c|}{219.829} & \multicolumn{3}{|c|}{497.890} & \multicolumn{3}{|c|}{576.999} \\
\hline \multirow{2}{*}{\multicolumn{2}{|c|}{$\begin{array}{l}\text { Prob (F-statistic) } \\
\text { Adiusted R-squa }\end{array}$}} & \multicolumn{2}{|c|}{0.000} & \multirow{2}{*}{\multicolumn{3}{|c|}{$\begin{array}{l}0.000 \\
0.734\end{array}$}} & \multirow{2}{*}{\multicolumn{3}{|c|}{$\frac{0.000}{0.762}$}} \\
\hline & & & & & & & & & \\
\hline \multicolumn{3}{|c|}{ Durbin-Watson stat } & & \multicolumn{3}{|c|}{1.843} & \multicolumn{3}{|c|}{1.991} \\
\hline
\end{tabular}

According to Table (6), the intercept in the three-month, six-month, and nine-month periods is $0.107,0.231$ and 0.378 , respectively. They are significant at a $1 \%$ level of significance with respect to the positive and 
significant intercepts, it can be said that the disposition effect on stocks with low liquidity increases the momentum profit in all three cases of three-month momentum, six-month momentum, and nine-month momentum. The F-statistic of the model in all three cases of three-month momentum, six-month momentum, and nine-month momentum is 219.829, 497.890, and 579.999, respectively. They are significant at a $1 \%$ level of significance.

As a sensitivity analysis, The Anchoring bias in stocks with low liquidity on the momentum profit is examined using the Fama-French five-factor models. Findings are presented in Table (7).

Table 7. Regression results for the effect of anchoring bias in stocks with low liquidity on momentum profit using the Fama-French model

\begin{tabular}{|c|c|c|c|c|c|c|c|c|c|}
\hline \multicolumn{10}{|c|}{$R_{i, t}-R_{f, t}=\beta_{0}+\beta_{1}\left(R_{m, t}-R_{f, t}\right)+\beta_{2}\left(S M B_{t}\right)+\beta_{3}\left(H M L_{t}\right)+\beta_{4}\left(R M W_{t}\right)+\beta_{4}\left(C M A_{t}\right)+\varepsilon_{i, t}$} \\
\hline \multicolumn{4}{|c|}{3 months momentum } & \multicolumn{3}{|c|}{6 months momentum } & \multicolumn{3}{|c|}{9 months momentum } \\
\hline $\begin{array}{c}\text { Variab } \\
\text { le }\end{array}$ & $\begin{array}{c}\text { Coefficie } \\
\text { nt }\end{array}$ & $\begin{array}{c}\mathrm{t}- \\
\text { Statist } \\
\text { ic }\end{array}$ & $\begin{array}{c}\text { Prob } \\
.\end{array}$ & $\begin{array}{c}\text { Coefficie } \\
\text { nt }\end{array}$ & $\begin{array}{c}\mathrm{t}- \\
\text { Statist } \\
\text { ic }\end{array}$ & Prob & $\begin{array}{c}\text { Coefficie } \\
\text { nt }\end{array}$ & $\begin{array}{c}\mathrm{t}- \\
\text { Statist } \\
\text { ic }\end{array}$ & $\begin{array}{c}\text { Prob } \\
.\end{array}$ \\
\hline $\mathrm{C}$ & 0.106 & 6.675 & $\begin{array}{c}0.00 \\
0 \\
\end{array}$ & 0.228 & 5.540 & $\begin{array}{c}0.00 \\
0 \\
\end{array}$ & 0.386 & 4.934 & $\begin{array}{c}0.00 \\
0 \\
\end{array}$ \\
\hline $\mathrm{R}_{\mathrm{m}-} \mathrm{R}_{\mathrm{f}}$ & 0.212 & 2.619 & $\begin{array}{c}0.00 \\
9\end{array}$ & 0.297 & 2.343 & $\begin{array}{c}0.01 \\
9\end{array}$ & 0.775 & 3.331 & $\begin{array}{c}0.00 \\
0\end{array}$ \\
\hline SMB & -0.137 & -0.912 & $\begin{array}{c}0.36 \\
2 \\
\end{array}$ & -0.492 & -2.029 & $\begin{array}{c}0.04 \\
2\end{array}$ & -0.334 & -0.998 & $\begin{array}{c}0.31 \\
8\end{array}$ \\
\hline HML & -0.043 & -0.543 & $\begin{array}{c}0.58 \\
7\end{array}$ & -0.159 & -1.149 & $\begin{array}{c}0.25 \\
1\end{array}$ & 0.108 & 2.050 & $\begin{array}{c}0.03 \\
1\end{array}$ \\
\hline RMW & 0.093 & 0.847 & $\begin{array}{c}0.39 \\
7\end{array}$ & 0.202 & 2.051 & $\begin{array}{c}0.03 \\
0\end{array}$ & 0.106 & 0.482 & $\begin{array}{c}0.63 \\
0\end{array}$ \\
\hline CMA & 0.374 & 3.640 & $\begin{array}{c}0.00 \\
0 \\
\end{array}$ & 0.236 & 1.293 & $\begin{array}{c}0.19 \\
6 \\
\end{array}$ & 0.600 & 2.538 & $\begin{array}{c}0.01 \\
1 \\
\end{array}$ \\
\hline $\mathrm{AR}(1)$ & 0.691 & 26.732 & $\begin{array}{c}0.00 \\
0\end{array}$ & 0.790 & 20.013 & $\begin{array}{c}0.00 \\
0\end{array}$ & 0.838 & 30.504 & $\begin{array}{c}0.00 \\
0\end{array}$ \\
\hline \multicolumn{2}{|c|}{ F-statistic } & \multicolumn{2}{|c|}{171.295} & \multicolumn{3}{|c|}{302.128} & \multicolumn{3}{|c|}{430.321} \\
\hline \multicolumn{2}{|c|}{ Prob(F-statistic) } & \multicolumn{2}{|c|}{0.000} & \multicolumn{3}{|c|}{0.000} & \multicolumn{3}{|c|}{0.000} \\
\hline \multicolumn{2}{|c|}{ Adjusted R-square } & \multicolumn{2}{|c|}{0.487} & \multicolumn{3}{|c|}{0.626} & \multicolumn{3}{|c|}{0.705} \\
\hline \multicolumn{2}{|c|}{ Durbin-Watson stat } & \multicolumn{2}{|c|}{1.834} & \multicolumn{3}{|c|}{2.080} & \multicolumn{3}{|c|}{2.085} \\
\hline & & & & e: Rese & Find & & & & \\
\hline
\end{tabular}

Based on Table (7), the intercept in the three-month, six-month, and ninemonth periods is $0.106,0.228$ and 0.386 , respectively. They are significant at a $1 \%$ level of significance. Concerning the positive and significant intercepts, it can be said that anchoring bias in low liquidity stocks increases momentum profits in all three cases. The F-statistic of the model in all three modes of three-month momentum, six-month momentum, and nine-month momentum is 
171.295, 302.122, and 430/330, respectively. They are significant at a $1 \%$ level of significance

The Results of the Fama-French model for testing the third research hypothesis are reflected in Table (8).

Table 8. Results of testing the third research hypothesis using the Fama-French model

\begin{tabular}{|c|c|c|c|c|c|c|c|c|c|}
\hline$R_{i, t}-R_{f}$ & $=\beta_{0}+1$ & $m, t$ & )+ & ${ }_{2}\left(S M B_{t}\right)$ & ${ }_{3}(H I$ & $+\beta_{4}$ & $\left.R M W_{t}\right)$ & $C N$ & $\varepsilon_{i, t}$ \\
\hline & months mo & nentum & & 6 montl & momen & & 9 month & s momen & \\
\hline $\begin{array}{c}\text { Variab } \\
\text { le }\end{array}$ & $\begin{array}{c}\text { Coefficie } \\
\text { nt }\end{array}$ & $\begin{array}{c}\mathrm{t}- \\
\text { Statist } \\
\text { ic }\end{array}$ & Prob & $\begin{array}{c}\text { Coefficie } \\
\text { nt }\end{array}$ & $\begin{array}{l}\mathrm{t}- \\
\text { Statist } \\
\text { ic }\end{array}$ & Prob & $\begin{array}{c}\text { Coefficie } \\
\text { nt }\end{array}$ & $\begin{array}{c}\mathrm{t}- \\
\text { Statist } \\
\text { ic }\end{array}$ & Prob \\
\hline $\mathrm{C}$ & 0.816 & 2.006 & $\begin{array}{c}0.04 \\
7\end{array}$ & 0.177 & 2.066 & $\begin{array}{c}0.04 \\
1\end{array}$ & 0.527 & 2.394 & $\begin{array}{c}0.01 \\
8\end{array}$ \\
\hline$R_{m-} R_{f}$ & -0.282 & -2.266 & $\begin{array}{c}0.02 \\
5 \\
\end{array}$ & -1.039 & -1.685 & $\begin{array}{c}0.09 \\
4 \\
\end{array}$ & -0.099 & -2.308 & $\begin{array}{c}0.01 \\
4\end{array}$ \\
\hline SMB & -0.189 & -2.780 & $\begin{array}{c}0.04 \\
7\end{array}$ & -1.484 & -1.369 & $\begin{array}{c}0.17 \\
4\end{array}$ & -0.488 & -0.311 & $\begin{array}{c}0.75 \\
6\end{array}$ \\
\hline HML & -0.050 & -0.131 & $\begin{array}{c}0.89 \\
5\end{array}$ & 1.124 & 1.843 & $\begin{array}{c}0.06 \\
8\end{array}$ & -0.523 & -2.100 & $\begin{array}{c}0.04 \\
0\end{array}$ \\
\hline RMW & -0.306 & -0.657 & $\begin{array}{c}0.51 \\
3\end{array}$ & -0.761 & -1.023 & $\begin{array}{c}0.30 \\
8\end{array}$ & -0.347 & -0.327 & $\begin{array}{c}0.74 \\
4\end{array}$ \\
\hline CMA & 0.265 & 0.523 & $\begin{array}{c}0.60 \\
2\end{array}$ & -1.172 & -1.450 & $\begin{array}{c}0.15 \\
0\end{array}$ & -0.513 & -0.440 & $\begin{array}{c}0.66 \\
1\end{array}$ \\
\hline $\mathrm{AR}(1)$ & 0.404 & 4.709 & $\begin{array}{c}0.00 \\
0\end{array}$ & 0546 & 6.816 & $\begin{array}{c}0.00 \\
0\end{array}$ & 0.735 & 11.566 & $\begin{array}{c}0.00 \\
0\end{array}$ \\
\hline & atistic & 4.62 & & & .593 & & & 2.930 & \\
\hline Prol & F-statistic) & 0.0 & & & .000 & & & .000 & \\
\hline Adju: & ed R-squa & & 56 & & 350 & & & 0.527 & \\
\hline Durb & -Watson $\mathrm{s}$ & & & & .069 & & & 2.141 & \\
\hline
\end{tabular}

According to the contents of Table (8), the intercept in the three-month, six-month, and nine-month momentum is $0.816,0.177$, and 0.527 , respectively. They are significant at a 5\% level of significance. These findings show that the interaction term of the anchoring bias and the disposition effect increase the momentum profit. The F-statistic in all three cases of three-month momentum, six-month momentum, and nine-month momentum is 4.627, 11.593, and 22.930 , respectively. They are significant at a $1 \%$ level of significance. The adjusted coefficient of determination in the three cases is $0.156,0.350$ and 0.527 , respectively.

The fourth hypothesis examines the interaction effect of anchoring bias and 
the disposition effect on the momentum profit when they reinforce each other and stocks have low liquidity. To test this hypothesis, initially, stocks were divided into two groups based on the liquidity variable. Then in each group to calculate the dependent variable, the difference between the mean returns of the portfolio with high disposition effect and high anchoring and the mean returns of the portfolio with low disposition effect and low anchoring subtract the difference between the mean returns of the portfolio with high disposition effect and low anchoring portfolio and the mean returns of the portfolio with low disposition effect and the high anchoring. Findings from the model are presented in Table (9).

Table 9. Results of testing the fourth research hypothesis with low liquidity using the Fama-French model

\begin{tabular}{|c|c|c|c|c|c|c|c|c|c|}
\hline \multicolumn{10}{|c|}{$R_{i, t}-R_{f, t}=\beta_{0}+\beta_{1}\left(R_{m, t}-R_{f, t}\right)+\beta_{2}\left(S M B_{t}\right)+\beta_{3}\left(H M L_{t}\right)+\beta_{4}\left(R M W_{t}\right)+\beta_{4}\left(C M A_{t}\right)+\varepsilon_{i, t}$} \\
\hline \multicolumn{4}{|c|}{3 months momentum } & \multicolumn{3}{|c|}{6 months momentum } & \multicolumn{3}{|c|}{9 months momentum } \\
\hline $\begin{array}{c}\text { Variab } \\
\text { le }\end{array}$ & $\begin{array}{c}\text { Coefficie } \\
\text { nt }\end{array}$ & $\begin{array}{c}\mathrm{t}- \\
\text { Statist } \\
\text { ic }\end{array}$ & Prob & $\begin{array}{c}\text { Coefficie } \\
\text { nt }\end{array}$ & $\begin{array}{c}\mathrm{t}- \\
\text { Statist } \\
\text { ic }\end{array}$ & Prob & $\begin{array}{c}\text { Coefficie } \\
\text { nt }\end{array}$ & $\begin{array}{c}\mathrm{t}- \\
\text { Statist } \\
\text { ic }\end{array}$ & Prob \\
\hline $\mathrm{C}$ & -0.067 & -1.458 & $\begin{array}{c}0.14 \\
7\end{array}$ & -0.149 & -1.725 & $\begin{array}{c}0.08 \\
7\end{array}$ & -0.291 & -1.701 & $\begin{array}{c}0.06 \\
1\end{array}$ \\
\hline $\mathrm{R}_{\mathrm{m}-} \mathrm{R}_{\mathrm{f}}$ & 0.178 & 0.456 & $\begin{array}{c}0.65 \\
0\end{array}$ & 0.121 & 2.020 & $\begin{array}{c}0.04 \\
1\end{array}$ & 1.671 & 1.720 & $\begin{array}{c}0.08 \\
8\end{array}$ \\
\hline SMB & -0.206 & -0.324 & $\begin{array}{c}0.74 \\
7\end{array}$ & -1.274 & -0.964 & $\begin{array}{c}0.33 \\
7\end{array}$ & -2.908 & -1.771 & $\begin{array}{c}0.07 \\
9\end{array}$ \\
\hline HML & -0.676 & -1.690 & $\begin{array}{c}0.09 \\
3 \\
\end{array}$ & 0.296 & 0.445 & $\begin{array}{c}0.65 \\
7 \\
\end{array}$ & -0.463 & -0.486 & $\begin{array}{c}0.62 \\
7 \\
\end{array}$ \\
\hline RMW & 0.934 & 1.410 & $\begin{array}{c}0.16 \\
1 \\
\end{array}$ & 1.175 & 0.922 & $\begin{array}{c}0.35 \\
8 \\
\end{array}$ & 2.768 & 2.456 & $\begin{array}{c}0.01 \\
6 \\
\end{array}$ \\
\hline CMA & -0.391 & -2.085 & $\begin{array}{c}0.03 \\
4\end{array}$ & -2.745 & -2.417 & $\begin{array}{c}0.01 \\
7 \\
\end{array}$ & 1.333 & -1.638 & $\begin{array}{c}0.10 \\
4\end{array}$ \\
\hline $\operatorname{AR}(1)$ & 0.290 & 3.144 & $\begin{array}{c}0.00 \\
2\end{array}$ & 0.269 & 1.740 & $\begin{array}{c}0.08 \\
4\end{array}$ & 0.501 & 4.628 & $\begin{array}{c}0.00 \\
0\end{array}$ \\
\hline \multicolumn{2}{|c|}{ F-statistic } & \multicolumn{2}{|c|}{2.396} & \multicolumn{3}{|c|}{2.222} & \multicolumn{3}{|c|}{6.598} \\
\hline \multicolumn{2}{|c|}{ Prob (F-statistic) } & \multicolumn{2}{|c|}{0.032} & \multicolumn{3}{|c|}{0.046} & \multicolumn{3}{|c|}{0.000} \\
\hline \multirow{2}{*}{\multicolumn{2}{|c|}{$\begin{array}{l}\text { Adjusted R- squared } \\
\text { Durbin-Watson stat }\end{array}$}} & \multirow{2}{*}{\multicolumn{2}{|c|}{$\frac{0.066}{2.034}$}} & \multirow{2}{*}{\multicolumn{3}{|c|}{$\frac{0.058}{2109}$}} & \multicolumn{3}{|c|}{0.221} \\
\hline & & & & & & & & 2.180 & \\
\hline \multicolumn{10}{|c|}{ Source: Research Findings } \\
\hline
\end{tabular}

According to the contents of the table (9), the intercept in the three-month, six-month, and nine-month periods is $-0.067,-0.149$, and -0.291 , respectively. Therefore, it can be stated that in a situation that stock liquidity is high, the interaction effect of anchoring bias and the disposition effect when they 
reinforce each other does not increase the momentum profit. Findings from the model to test the fourth hypothesis when stock liquidity is low are reflected in Table (10).

Table 10. Results of testing the fourth research hypothesis with low liquidity using the Fama-French model

\begin{tabular}{|c|c|c|c|c|c|c|c|c|c|}
\hline$R_{i, t}-R_{f}$ & $=\beta_{0}+\beta$ & $R_{m, t}-$ & $t)+$ & ${ }_{2}\left(S M B_{t}\right)$ & $\beta_{3}(H M L$ & )$+\beta_{4}$ & $\left.R M W_{t}\right)$ & $(C M A$ & $+\varepsilon_{i, t}$ \\
\hline & months mo & nentum & & 6 mont & s momen & & 9 montl & is momen & \\
\hline $\begin{array}{c}\text { Variab } \\
\text { le }\end{array}$ & $\begin{array}{c}\text { Coefficie } \\
\text { nt }\end{array}$ & $\begin{array}{c}\mathrm{t}- \\
\text { Statist } \\
\text { ic }\end{array}$ & Prob & $\begin{array}{c}\text { Coefficie } \\
\text { nt }\end{array}$ & $\begin{array}{l}\mathrm{t}- \\
\text { Statist } \\
\text { ic }\end{array}$ & Prob & $\begin{array}{c}\text { Coefficie } \\
\text { nt }\end{array}$ & $\begin{array}{l}\mathrm{t}- \\
\text { Statist } \\
\text { ic }\end{array}$ & Prob \\
\hline $\mathrm{C}$ & -0.018 & -0.281 & $\begin{array}{c}0.77 \\
9\end{array}$ & -0.035 & -0.312 & $\begin{array}{c}0.74 \\
9\end{array}$ & -0.480 & -1.971 & $\begin{array}{c}0.05 \\
1\end{array}$ \\
\hline $\mathrm{R}_{\mathrm{m}-} \mathrm{R}_{\mathrm{f}}$ & -0.379 & -0.506 & $\begin{array}{c}0.61 \\
4 \\
\end{array}$ & -2.491 & -1.802 & $\begin{array}{c}0.07 \\
4 \\
\end{array}$ & -2.299 & -0.916 & $\begin{array}{c}0.36 \\
2 \\
\end{array}$ \\
\hline SMB & -0.941 & -0.997 & $\begin{array}{c}0.32 \\
1\end{array}$ & -1.390 & -0.377 & $\begin{array}{c}0.70 \\
7\end{array}$ & -0.238 & -0.044 & $\begin{array}{c}0.96 \\
5\end{array}$ \\
\hline HML & 1.610 & 1.131 & $\begin{array}{c}0.26 \\
0\end{array}$ & 6.543 & 2.100 & $\begin{array}{c}0.03 \\
8\end{array}$ & 2.895 & 2.089 & $\begin{array}{c}0.03 \\
5 \\
\end{array}$ \\
\hline RMW & -2.389 & -1.804 & $\begin{array}{c}0.07 \\
4\end{array}$ & -4.688 & -2.116 & $\begin{array}{c}0.03 \\
6\end{array}$ & -5.671 & -3.567 & $\begin{array}{c}0.02 \\
0\end{array}$ \\
\hline CMA & 2.558 & 2.053 & $\begin{array}{c}0.02 \\
8\end{array}$ & -1.629 & -0.574 & $\begin{array}{c}0.56 \\
7\end{array}$ & 2.635 & 0.631 & $\begin{array}{c}0.53 \\
0 \\
\end{array}$ \\
\hline $\mathrm{AR}(1)$ & 0.086 & 2.042 & $\begin{array}{c}0.03 \\
9\end{array}$ & 0.089 & 1.008 & $\begin{array}{c}0.31 \\
5\end{array}$ & 0.323 & 2.097 & $\begin{array}{c}0.03 \\
8\end{array}$ \\
\hline & atistic & 4.38 & & & 4.360 & & & 4.298 & \\
\hline Pro & F-statistic) & & & & 0.000 & & & 0.000 & \\
\hline Adju & ed R-squa & & 56 & & 0.146 & & & 0144 & \\
\hline Durl & 1-Watson $\mathrm{s}$ & & 82 & & 2.009 & & & 2.072 & \\
\hline
\end{tabular}

As can be seen in Table (10), the intercept in the three-month, six-month, and nine-month periods are $-0.018,-0.035$ and -0.480 , respectively, and their significance level is equal to $0.779,0.749$ and 0.051 respectively. Therefore, the intercept is not significant, so it can be said that in a situation that stock liquidity is low, the interaction effect of anchoring bias and disposition effect when they reinforce each other does not increase the momentum profit. Thus, the fourth hypothesis of the research is rejected. 


\section{Conclusion}

The purpose of the present study is to investigate the effect of anchoring bias and disposition effect on the momentum profit and also the role of stock liquidity on this relationship. Therefore, this study develops four hypotheses and uses the multivariate regression and the five-factor model of Fama and French (2015). Findings indicate that the disposition effect in the stocks with low liquidity increases momentum profit. It means that the momentum arises from the disposition effect proposed by Shefrin and Statman (1985). Investors are tended to sell stocks with accumulated capital gains and this action gives them the good news that prices will change more slowly during the holding period and there will be continued returns.

The finding of this study is consistent with Grinblatt and Han (2005), Goetzmann, Massa (2008), Hur and Singh (2019) Findings of this study document the effect of anchoring bias in stocks with low liquidity in increasing momentum profit. It is argued that anchoring at the 52 weeks high price delays the arrival of the good (bad) news in the company's stock price. So that investors offer instantly sale of stocks, which causes high or low stock prices and leads to an increase in momentum, and the lack of liquidity of stocks also intensifies the mispricing of shares, and consequently, the momentum profits will increase.

These findings are consistent with George and Hwang (2004), Chen and Yang (2016), O'Brien and Best (2017) and Hur and Singh (2019) who proposed anchoring as a substitute stimulus in explaining the stock price momentum. The current study documents when the anchoring bias and the disposition effect reinforce each other, the momentum profit increases. These results confirm that investors with the disposition effect hold their loser stocks and are eager to sell winner stocks, as they believe that loss stock prices will increase and stocks with capital gains will decrease (Hur and Singh, 2019). These findings are consistent with George and Hwang, who stated that loser stocks would be priced higher and winner stocks would be priced lower. Therefore, the interaction effect of disposition effect and anchoring bias on mispricing stock delays the flow of information in pricing and leads to momentum amplification.

The findings of this study do not support the argument that the interaction effect of anchoring bias and disposition effect in the stocks with low liquidity increase momentum profit. It is argued that shareholders are more affected by disposition effect and anchoring bias which lead to slow down the flow of information to the stock and high and low stock pricing, however, the 
interaction of these two biases with liquid stocks does not lead to increase momentum profit. These findings are not consistent with George and Hwang (2004), Hur et al (2010) and Hur and Singh (2019). They showed that the disposition effect and anchoring bias in stocks with low liquidity intensifies the momentum profit. Establishing mechanisms in the capital market through education, setting rules and regulations according to market conditions seems necessary to increase the liquidity of stocks. A momentum strategy is a marketoriented investment strategy. This study shows that behavioral biases such as disposition effect and anchoring increase the momentum profits.

Therefore, investors are advised to take the advantage of the opportunities created in the capital market by recognizing these biases and their interaction on returns and to adopt the best profitable strategy for their investments. Based on the results of the present study, it is recommended to researchers that examine the interaction of other behavioral and emotional aspects such as availability bias and representativeness bias or self-attribution bias and conservative bias and narrow framing bias and recency effect bias and modernity bias in stocks with low, medium and high liquidity on momentum profits. By expanding information and recognizing the various dimensions of the market, the best conditions are provided for investors to make appropriate and correct investment decisions and strategies. It is also suggested that due to the expansion of investment companies and specialized holdings in the capital market and the role of these industries in capital market transactions the studies conducted in this research should be done in a sample of investment companies or specialized holdings.

\section{Declaration of Conflicting Interests}

The authors declared no potential conflicts of interest concerning the research, authorship and, or publication of this article.

\section{Funding}

The authors received no financial support for the research, authorship and, or publication of this article. 


\section{References}

Ahmed, MS., Doukas JA. (2021). Revisiting disposition effect and momentum: a quantile regression perspective, Review of Quantitative Finance and Accounting, 56, pages 1087-1128.

Aiteken, M.J., \& Winn, R. (1997). What is this thing called liquidity? Working Paper. Securities Industry Research Center of Asia-Pacific Sydney, Australia.143-163.

Amihud, Y. (2002). Illiquidity and stock return: cross-section and time-series effects. Journal of Financial Markets 5, 31-56.

An, L. (2016), Asset pricing when traders sell extreme winners and losers, Review of Financial Studies, 29(3), 823-861. 56.

Aragon, G. O., \& Dieckmann, S. (2011), Stock market trading activity and returns around milestones, Journal of Empirical Finance 18(4), 570-584. 56.

Asness, C. S., \& Moskowitz, T. J., \& Pedersen, L. H. (2013), Value and momentum everywhere, Journal of Finance 68(3), 929-985. 11, 12, 21, 27

Auret, CH., \&Page, D. (2013), Momentum and liquidity on The Johannesburg Stock Exchange, International Journal of Economics and Finance Studies, 5, 1, 5673.

Avramov, Doron, Tarun Chordia, Gergana Jostova, and Alexander Philipov (2007), Momentum and credit rating." The Journal of Finance, 62, 2503-2520.

Badri, ahmad \&Fath Elahi (2014). Momentum Returns: Evidence from the Tehran Stock Exchange. Investment Knowledge Quarterly, 9.20-1.

Baker, M., \& Pan, X, \& Wurgler, J. (2012), the effect of reference point prices on mergers and acquisitions, Journal of Financial Economics 106(1), 49-71. 3, 18, $56,57,100$.

Ball, C. A., \& Torous, W. N, \& Tschoegl, A. E. (1985), the degree of price resolution: The case of the gold market, Journal of Futures Markets, 5, 29-43. 103.

Barber, B. M., \& Odean, T. (2007), all that glitters: The effect of attention and news on the buying behavior of individual and institutional investors, Review of Financial Studies 21(2), 785-818. 19, 48, 55, 100, 101, 102, 122.

Barberis, N., Huang, M., \& Thaler, R. H. (2006). Individual preferences, monetary gambles, and stock market participation: A case for narrow framing.American Economic Review,96(4), 1069-1090.

Ben-David, I., \& Hirshleifer, D. (2012), Beyond the disposition effect: Do investors really like realizing gains more than losses, Review of Financial Studies 25(8), 2485-2532. 65, 100, 103. 
Bernard, V., \& Thomas, J. (1990). Evidence that stock prices do not fully reflect the implications of current earnings. Journal of Accounting and Economics, 13, 305-341

Bhattacharya, A., \& O'Hara, M. (2018), can etfs increase market fragility? effect of information linkages in etf markets, Effect of Information Linkages in ETF Markets, 100

Bian, J., \& Chan, K., Shi, D., \& Zhou, H. (2018), do behavioral biases affect order aggressiveness? Review of Finance, 22(3), 1121-1151. 59, 64, 102.

Birru, J. (2015), Psychological barriers, expectational errors, and underreaction to news, Charles A. Dice Center Working, 2014-03, 10, 14, 17, 57, 86, 88, 96, 97, 100, 101, 104, 118.

Birru, J. (2015), Psychological barriers, expectational errors, and underreaction to news', Charles A. Dice Center Working Paper, 10, 14, 17, 57, 86, 88, 96, 97, 100, 101, 104, 118.

Blau, B., \& DeLisle, R. J., \& Whitby, R. (2020), Does Probability Weighting Drive Lottery Preferences, Journal of Behavioral Finance, 21 (3), 233-247.

Boehmer, E., \& Kelley, E. (2009).Institutional Investors and the Informational Efficiency of Prices. The Review of Financial Studies. 22 (9), 3563-3594.

Box, T., \& Griffith, T. (2016), Price clustering asymmetries in limit order flows, Financial Management 45(4), 1041-1066. 103.

Brown, J. A., \& Martin, J. (2008) Global momentum strategies. Journal of Portfolio bias. Journal of Portfolio Management, 34, 103-25.

Chan, CH., N. Jegadeesh. , \& Lakonishok, J. (1996). Momentum Strategies. Journal of Finance, 51, 1681-1713.

Chan, K., \& Hameed, A., \& Tong, W. (2000), Profitability of momentum strategies in the international equity markets, Journal of Financial and Quantitative Analysis 35(2), 153-172. 12

Chen, A., \& Yang, W. (2016). Echo effects and the returns from 52-week high strategies. Finance Research Letters, 16, 38-46.

Chen, Z.,\& Ibbotson, R., \& Hu, W., (2010), Liquidity as an Investment Style, Zebra Capital Management and Yale School of Management, Electronic copy available at: http://ssrn.com/abstract=1675108

Chi Hsu, ching\& Chien, Fengsheng. (2020). The Impact of Anchoring Bias on the Profitability of Time- Series Momentum. Revista Argentina de clinica Psicologica, vol. XXXIX, N4, 169-177

Chiao, C., \& Wang, Z.-M. (2009), Price clustering: evidence using comprehensive limit-order data, The Financial Review 44(1), 1-29. 103. 
Chordia, T., \& Roll, R., \& Subrahmanyam, A. (2011). Recent trends in trading activity and market quality. Journal of Finance and Economics. 101, 243-263.

Chordia, T., \& Subrahmanyam, A., \&Tong, Q. (2014). Have capital market anomalies attenuated in the recent era of high liquidity and trading activity? Journal of Finance and Economics. 58, 41-58.

Chui, A. C.,\& Titman, S. \& Wei, K. J. (2010), Individualism and momentum around the world, Griffin, J. M., \& Ji, X. 7 Martin, J. S. (2003), Momentum investing and the business cycle. Risk: Evidence from pole to pole, Journal of Finance 58(6), 2515-2547. 12

Clement, E. (2021), Remembering Richard H.Driehause, Business Exchange: Vol1:iss.15.Article 3. Available at: https://Via.library.depaul.edu/bx/Vol1/iss $15 / 3$

Daniel, K., \& Hirshleifer, D., \& Subrahmanyam, A. (1998), Investor psychology and security market under-and overreactions, Journal of Finance 53(6), 1839-1885. 57.

Fama, E. F., \& French, K. R. (2012), Size, value, and momentum in international stock returns, Journal of Financial Economics 105(3), 457-472. 12

Fama, E.F. \& French, K.R. (2015). A five-factor asset pricing model. Journal of Financial Economics, 116(1), 1-22.

Fedenia, M., \& Grammatikos, T. (1992), Options trading and the bid-ask spread of the underlying stocks, Journal of Business, 335-351, 103.

Festinger, L. (1957). A theory of cognitive dissonance. Stanford University Press, Psychological Theories from a Structuralist Point of View, 33-62.

Foster, G., Olsen, CH., \& Shevlin, T. (1984). Earnings releases, anomalies, and the behavior security returns. The Accounting Review, 59, 574-603.

Frazzini, A. (2006). The disposition effect and under-reaction to the news. Journal of Finance, 61, 2017-2046.

George, T. J., \& Hwang, C. Y. (2004). The 52-week high and momentum investing. Journal of Finance, 59 (5), 2145-2176.

Goetzmann, W., \& Massa, M.(2008). Disposition matters: Volume, volatility and price impact of a behavioral. Journal of Trading 3(2):68-90

Grinblatt, M., \& Han, B. (2005), Prospect theory, mental accounting, and momentum, Journal of Financial Economics 78(2), 311-339. 1, 14, 32, 52, 53, 56, 67, 69,122

Grinblatt. M., \& Titman, S. (1989). Mutual fund performance: an analysis of quarterly rewards to momentum investing. Review Financial Study, 14, 29-79. 
Hao, Y., Chou, R., Ko, K., \& Yang, N. (2018). The 52-week high, momentum, and investor sentiment, International Review of Financial Analysis, 57, 167-183.

Hao, Y., Hsiang-Hui. D., Keng-Yu. D. \& Kuan-Cheng, D. (2016). The 52-week high and momentum in the Taiwan stock market: Anchoring or recency biases?" International Review of Economics and Finance, 43, 121-138.

Hartzmark, S., 2015, The Worst, the Best, Ignoring All the Rest: The Rank Effect and Trading Behavior, Review of Financial Studies 28, 1024-1059.

Hendershott, T., \& Riordan, R. (2011). High-Frequency Trading and Price Discovery. The University of California at Berkeley Working Paper. The Review of Financial Studies 27, 2267-2306

Hong, H., \& Lim, T., \& Stein, J. C. (2000), Bad news travels slowly: size, analyst coverage, and the profitability of momentum strategies, Journal of Finance 55(1), 265-295. 13, 25, 44

Hong, H., \& Stein, J. C. (1999), A unified theory of underreaction, momentum trading, and overreaction in asset markets, Journal of Finance 54(6), 2143 2184. 2, 3, 5, 8, 10,11, 13, 24, 25, 44, 48, 105

Huddart, S., \& Lang, M, \& Yetman, M. H. (2009), Volume and price patterns around a stock's 52-week highs and lows: theory and evidence, Management Science 55(1), 16-31. i, 3, 52, 53, 54, 56, 62, 70.

Hur, J., \& Pritamani, M., \& Sharma, V. (2010), Momentum and the disposition effect: the role of individual investors, Financial Management, 39(3), 1155-1176. 10, $23,35,56$.

Hur, J., \& Singh, V. (2019). How do disposition effect and anchoring bias interact to impact momentum in stock returns? Journal of Empirical Finance, 53, 238-256.

Ikenberry, D. L, \&Weston, J. P. (2008), Clustering in us stock prices after decimalisation, European Financial Management 14(1), 30-54, 103.

Jegadeesh, N., Titman, S. (2001). Profitability of momentum strategies: An examination of alternative explanations. Journal of Finance, 56, 699-720.

Jones, CH., Charles P., \& Robert, H., Litzenberger, E. D. (1970). Quarterly earnings reports and intermediate stock price trends. https://doi. org/10. 1111/j. 15406261. 1970. tb00420. $x$

Kahnemann, D., \& Tversky, A. (1979). Prospect theory: An analysis of decision under risk, Econometric a, 47, 263-291.

Kelley, E. K., \& Tetlock, P. C. (2013), How wise are crowds? Insights from retail orders and stock returns, Journal of Finance, 68(3), 1229-1265. 4, 58, 77, 85, 89, 96, 102. 
Korajczyk, RA., \& Sadka, R. (2004), Are momentum profits robust to trading costs? , Journal of Finance, 59, 1039-1082.

Latane, H., \& Jones, CH.) 1979 (. Standardized unexpected earnings. Journal of Finance, 34, 717-724.

Lee, C., \& Swaminathan, B. (2000), Price momentum and trading volume, Journal of Finance, 55, 2017-2069.

Linnainmaa, J. T. (2010), Do limit orders alter inferences about investor performance and behavior? Journal of Finance, 65(4), 1473-1506. 53, 58, 72, 76, 77, 96, 98, $102,120$.

McInish, T. H., \& Wood, R. A. (1992), an analysis of intraday patterns in bid/ask spreads for NYSE stocks, Journal of Finance, 47(2), 753-764. 103, 107.

O'Brien, J., \& Best, P. (2017). Momentum, the Disposition Effect and Beta. Available at SSRN: https://ssrn. com/abstract=3124857

Pástor, L., \& Stambaugh, RF (2003), Liquidity risk and expected stock returns, Journal of Political Economy, 111, 642-685.

Peng, L., \& Xiong, W. (2006), Investor attention, overconfidence and category learning, Journal of Financial Economics 80(3), 563-602. 57, 101.

Roll, R., \& Schwartz, E., \& Subrahmanyam, A. (2007). Liquidity and the law of one price: The case of the futures/cash basis. Journal of Finance 62, 2201-2234.

Sadka, R. (2006), Momentum and Post-earnings-announcement Drift Anomalies: The Role of Liquidity Risk, Journal of Financial Economics 80,309-49.

Shefrin H., \&. Statman, M. (1985). The disposition to sell winners too early and ride losers too long: Theory and evidence, Journal of Finance, 40, 777-790.

Shiller, R. J. (2000), Irrational Exuberance, 6, Princeton University Press, Journal of Economics, 77, 202-205.

Tan, Y.M., Cheng, F.F. (2019).Industry and liquidity-based momentum in Australian equities, financial innovation, 2-18.

Thaler, R, \& Benartzi, S. (1985), does the stock market overreact? Journal of Finance 40(3), 793-805. 12

Tversky, A., \& Kahneman, D. (1974), Judgment under uncertainty: heuristics and biases, Science 185(4157), 1124-1131. 12, 55, 57, 70

Tversky, A., \& Kahneman, D. (1992), Advances in prospect theory: cumulative representation of uncertainty, Journal of Risk and Uncertainty, 5(4), 297-323. 4, 70,100.

Wang, H., \&Yan, J, \& Yu, J. (2017), Reference-dependent preferences and the riskreturn trade-off, Journal of Financial Economics 123(2), 395-414. 56. 
Yuan, Y. (2015), Market-wide attention, trading, and stock returns, Journal of Financial Economics 116(3), 548-564. 56.

Zamani, Sh., \& Faghani Kondari, P. (2015) ، calculating the liquidity of Tehran Stock Exchange and examining its effective factors. Tehran Financial Management Perspectives, 15.80-61.

\section{Bibliographic information of this paper for citing:}

Soltani, Fatemeh; Soroushyar, Afsaneh \& Fooladi, Masoud (2022). The Impact of Anchoring Bias and Disposition Effect on Momentum Profit: The Role of Stock Liquidity. Iranian Journal of Finance, 6(1), 83-116.

Copyright (C) 2022, Fatemeh Soltani, Afsaneh Soroushyar and Masoud Fooladi

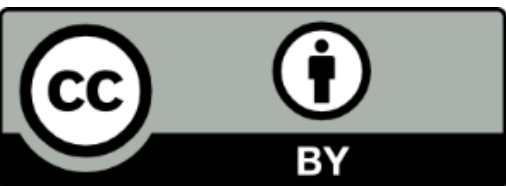

